\title{
IS FISCAL POLICY EFFECTIVE IN GENERATING HIGHER REAL OUTPUT? A CASE OF PAKISTAN
}

\author{
HAFIZ SAQIB MEHMOOD NAJMI \\ M. Phil. Scholar of Economics, \\ Lahore Leads University, Lahore \\ FURRUKH BASHIR \\ Lecturer of Economics, \\ The Islamia University of Bahawalpur, Pakistan. \\ Bahawalnagar Campus \\ Email: farrukh.bashir@iub.edu.pk
}

SAMAN MAQSOOD

M. Sc. Scholar of Economics,

The Islamia University of Bahawalpur, Pakistan.

Bahawalnagar Campus

\begin{abstract}
Keeping in view the objective that is to observe the usefulness of fiscal policy on real GDP of Pakistan, the study collects time series data from 1976 to 2012 through reliable sources of statistical bureaus of Pakistan. Using Johansen Cointegration test, the long run results demonstrate investment and government expenditure as raising factor for real GDP of Pakistan while GDP Deflator and government revenue as de-motivating factor for real GDP of Pakistan in the long run.
\end{abstract}

Keywords: Government Expenditure, Government Revenue, Real GDP, GDP Deflator, Investment.

JEL Classification Codes: C32, E13, E22, E24, E31, H20, H30, H50

\section{INTRODUCTION}

Fiscal policy means planning of expenditure and tax rate by the government to stimulate the economic activities. Macroeconomics, particularly the Keynesian school of thought, suggested that government spending speed up economic growth. Thus, government expenditure is considered as an exogenous power that changes cumulative output. 
There are two conceptually opposite views about the role of government. First, government spending is expected to be unfavorable to economic growth due to inefficient methods of allocating resources, favoring excess employment and under pricing of output to maintain the power. In addition, public spending started by greatly subsidized stateowned monopolies that reduce potential for private investment and long-run economic growth. Another reason is that financing of public expenditures through external and internal indebtedness imposes too much burdens on the economic system resulting in undesirable effects on economic growth.

Second, Government plays a serious role in matching disagreement between the social and private benefit and in providing a socially best way for development. Government can make product markets that work more competently and create significant spillover effects for private sector. Few studies state that fiscal policy has a positive relationship with the real GDP by creating employment and generating higher income of the people leading to an increase in the aggregate demand. The increased aggregate demand will give an incentive to the producers to increase their output.

Ghali (2003) investigated Government spending as having accelerating effect on economic growth in Tunisia. The policy effects according to the endogenous growth theory are opposite to that of neoclassical theory which argues that changes in tax rate may have an impact on growth [Romer (1986, 1990); Lucas (1988); Rebelo (1991); Jones (1993); Aghion and Howitt (1992); Kim (1992) and Gomme (1993)].

Taking into mind, the objective of this study is to present the influence of fiscal policy on real GDP of Pakistan using time series data from 1976 to 2012. This study is further divided into Literature Review, Data and Methodology, Results and Discussions, Concluding Remarks and Suitable Policy in sections 2, 3, 4, and 5.

\section{LITERATURE REVIEW}

This section provides summary of few studies related to fiscal policy and economic growth as below;

Ghali (1997) observed Intertemporal exchanges between the growth rate of per capita real GDP and the share of government expenditure in GDP using vector auto regressive method for the results. The study found no evidence in Saudi Arabia regarding influence of government spending on per capita output growth. 
Doessel and Valadkhani (2003) examined relationship between size of government and the process of economic growth in Fiji using annual time series data for the period 1964-1999. The study concluded that government expenditure exerted a strong beneficial impact on economic growth. Loizides and Vamvoukas (2005) explored the relationship between government size growth and income growth in both bi-variate and trivariate system. Using time series data of Greece, UK and Ireland, the analysis showed government size granger causing economic growth in the long run as well as in the short run.

Alexiou (2009) discovered the relationship between economic growth and government spending for seven countries in the South Eastern Europe region for the period 1995 to 2005. The empirical evidence indicated that Government Spending on capital formation, development assistance, private investment and trade openness had positive and significant effect on economic growth. Padda and Akram (2009) focused on tax rate changes adopted by South Asian countries having an impact on economic growth and probed changes in tax rate as negative for short term on economic growth.

Nurudeen and Usman (2010) attempted to investigate the effect of government expenditure on economic growth. The study revealed that government total capital expenditure, total recurrent expenditures, and government expenditure on education had negative effect on economic growth. On the contrary, rising government expenditure on transport and communication, and health resulted an increase in economic growth.

Asghar et al. (2011) intended to observe empirically the effect of government spending in social sectors on economic growth for the period 1974 - 2008 in Pakistan and revealed the existence of positive relationship between government expenditure on human capital and economic and community services and economic growth. On the other side, government expenditure on law and order and subsidies appeared to be negative for economic growth.

Al Bataineh (2012) concluded government expenditure at the aggregate level as positive impact on GDP growth using time series data for the period $1990-2010$ for Jordan. Nworji et al. (2012) studied the impact of public expenditure on economic growth in Nigeria based on time series data for the period 1970 - 2009 using ordinary least square method. Analysis illustrated that capital and recurrent expenditure on social and community services and recurrent expenditure on transfers had positive effect on economic growth. 
Ferede and Dahlby (2012) examined Canadian provincial governments' tax rates on economic growth using panel data over the period from 1977 - 2006 and concluded corporate tax rate and sales tax rate as negatively associated with growth rate of GDP per capita. Atif et al. (2012) empirically tested taxes, inflation and bank loans and investment on economic growth using ordinary least square method in Pakistan and indicated no effect of taxes on economic growth by utilizing annual data set from 1981 to 2010 .

Aladejare (2013) indicated dynamic interactions between government capital and recurrent expenditure and economic growth in Nigeria. The study discovered positive impact of Government capital, recurrent expenditure on economic growth.

\section{DATA AND METHODOLOGY}

Data, methodology and model specification are highlighted in this section.

\section{A. DATA AND METHODS}

Time series annual data is collected in this study over the period from 1976 to 2012. Data on all the variables are collected through Handbook Statistics on Pakistan Economy 2010 and Economic Survey of Pakistan (2012 - 13) which are reliable sources for economy of Pakistan. For calculation of elasticities, log $-\log$ form of the models are utilized. Results are estimated using Johansen Cointegration approach involving following steps;

1. Applying Unit root test (ADF) to know stationary of the variables for deciding about an appropriate estimation technique. If all variables are integrated of order 1, so Johansen Cointegration technique is considered as best one.

2. At second step, choosing an appropriate lag length of the models is necessary to be confirmed.

3. After finalizing an appropriate lag length, long run results are calculated using Johansen Cointegration test.

4. For short run estimates, vector error correction model is applied.

\section{B. MODEL DESCRIPTION}

Keeping in view the importance of fiscal policy, the study includes government expenditure and government revenue in the models specified below;

$$
R G D P=\alpha_{0}+\alpha_{1} E L F+\alpha_{2} I N V+\alpha_{3} G D P D E F+\alpha_{4} G E X P+u_{i}
$$




$$
R G D P=\beta_{0}+\beta_{1} E L F+\beta_{2} I N V+\beta_{3} G D P D E F+\beta_{4} G R E V+v_{i}
$$

In the above models, RGDP is real gross domestic product, ELF denotes employed labor force, INV indicates investment, GDPDEF shows GDP Deflator, GEXP represents government expenditure and GREV signifies government revenue. The inclusion of Employed Labor force and investment shows Solow growth model used in the current study. All variables are in natural log form. Hypotheses of the study are provided in table 1.

\section{Table 1: Hypothesis}

\begin{tabular}{lccc}
\hline Variables & Description & Unit of Measurement & $\begin{array}{c}\text { Expected } \\
\text { Relationship }\end{array}$ \\
\hline RGDP & $\begin{array}{c}\text { Real Gross domestic } \\
\text { product }\end{array}$ & Million rupees & Dependent Variable \\
\hline ELF & $\begin{array}{c}\text { Employed Labor } \\
\text { Force }\end{array}$ & Million & Positive \\
\hline INV & Investment & Million Rupees & Positive \\
\hline GDPDEF & GDP Deflator & Price Index & Negative \\
\hline GEXP & $\begin{array}{c}\text { Government } \\
\text { Expenditure }\end{array}$ & Million Rupees & Positive \\
\hline GREV & $\begin{array}{c}\text { Government } \\
\text { Revenue }\end{array}$ & Million Rupees & Negative \\
\hline$\alpha_{0}$ and $\beta_{0}$ are elasticities of real GDP with respect to various variables. \\
\hline $\mathrm{U}_{\mathrm{i}}$ and $\mathrm{v}_{\mathrm{i}}$ are error terms & & \\
\hline
\end{tabular}

\section{RESULT AND DISCUSSION}

The results of this study are discussed in this section comprising of unit root test, lag length selection, Johansen Cointegration test and vector error correction model.

\section{A. UNIT ROOT RESULT}

For estimation of econometric results, first step is required to identify stationary level of all the variables. For that purpose, Augmented Dickey Fuller test is utilized that provide confirmation about all the variables having order of integration as 1. In other words, we can say that Real GDP, Investment, Employed Labor Force, Government Revenue, Government Expenditure and GDP Deflator are stationary at first difference. Table 2 reports the results of ADF test. 
Table 2: ADF Unit Root Test

\begin{tabular}{|c|c|c|c|c|c|}
\hline \multirow[b]{2}{*}{ Variables } & \multirow[b]{2}{*}{$\begin{array}{l}\text { Tests for } \\
\text { Unit Root in }\end{array}$} & \multirow[b]{2}{*}{$\begin{array}{c}\text { Include in } \\
\text { Test } \\
\text { Equation }\end{array}$} & \multicolumn{2}{|c|}{ Test Statistics } & \multirow[b]{2}{*}{ Results } \\
\hline & & & $\begin{array}{l}\text { ADF test } \\
\text { statistics }\end{array}$ & $\begin{array}{c}\text { ADF } \\
\text { Critical } \\
\text { Value } \mathbf{0 . 0 5}\end{array}$ & \\
\hline \multirow{3}{*}{ Real GDP } & & Intercept & -1.24599 & -2.945842 & \multirow{3}{*}{$\mathrm{I}(1)$} \\
\hline & Level & $\begin{array}{l}\text { Trend and } \\
\text { Intercept }\end{array}$ & -2.43842 & -3.540328 & \\
\hline & 1st Difference & Intercept & -6.10357 & -2.948404 & \\
\hline \multirow{3}{*}{ Investment } & & Intercept & 0.58275 & -2.94585 & \multirow{3}{*}{$\mathrm{I}(1)$} \\
\hline & Level & $\begin{array}{l}\text { Trend and } \\
\text { Intercept }\end{array}$ & -2.82086 & -3.54033 & \\
\hline & 1st Difference & Intercept & -5.29938 & -2.948405 & \\
\hline \multirow{3}{*}{$\begin{array}{l}\text { Government } \\
\text { Revenue }\end{array}$} & & Intercept & -1.66134 & -2.94585 & \multirow{3}{*}{$\mathrm{I}(1)$} \\
\hline & Level & $\begin{array}{l}\text { Trend and } \\
\text { Intercept }\end{array}$ & -2.22942 & -3.54033 & \\
\hline & 1st Difference & Intercept & -4.07176 & -2948404 & \\
\hline \multirow{3}{*}{$\begin{array}{l}\text { Government } \\
\text { Expenditure }\end{array}$} & & Intercept & -0.75389 & -2.94585 & \multirow{3}{*}{$\mathrm{I}(1)$} \\
\hline & Level & $\begin{array}{l}\text { Trend and } \\
\text { Intercept }\end{array}$ & -2.06149 & -3.540328 & \\
\hline & 1st Difference & Intercept & -3.84358 & -2.948404 & \\
\hline \multirow{3}{*}{$\begin{array}{l}\text { GDP } \\
\text { Deflator }\end{array}$} & & Intercept & -0.52976 & -2.945842 & \multirow{3}{*}{$\mathrm{I}(1)$} \\
\hline & Level & $\begin{array}{l}\text { Trend and } \\
\text { Intercept }\end{array}$ & -1.79233 & -3.540328 & \\
\hline & 1st Difference & Intercept & -5.67168 & -2.948404 & \\
\hline \multirow{3}{*}{$\begin{array}{l}\text { Employed } \\
\text { Labor Force }\end{array}$} & & Intercept & -0.36877 & -2.945842 & \multirow{3}{*}{$\mathrm{I}(1)$} \\
\hline & Level & $\begin{array}{l}\text { Trend and } \\
\text { Intercept }\end{array}$ & -1.94905 & -3.540328 & \\
\hline & 1st Difference & Intercept & -6.37347 & -2.948404 & \\
\hline
\end{tabular}

\section{B. LAG LENGTH SELECTION PROCESS}

The second step of Johansen Co-integration technique necessitates selection of appropriate lag length using proper information criterions. In table 3, Lag Length Selection results are reported that verifies ' 1 ' as suitable lag length at which values of Akaike Information Criterion (AIC), Schwarz Information Criterion (SC) and Hannan - Quinn information Criterion $(\mathrm{HQ})$ are minimum.

Table 3: Lag length Selection

\begin{tabular}{ccccc}
\hline Models & Lag & AIC & SC & HQ \\
\hline \multirow{3}{*}{ I } & 0 & -2.334430 & -2.112237 & -2.257729 \\
\cline { 2 - 5 } & 1 & $-12.27446^{*}$ & $-10.94130^{*}$ & $-11.81425^{*}$ \\
\cline { 2 - 5 } & 2 & -12.10449 & -9.660376 & -11.26078 \\
\hline \multirow{3}{*}{ II } & 0 & -2.698130 & -2.475938 & -2.621429 \\
\cline { 2 - 5 } & 1 & $-12.53924^{*}$ & $-11.20609^{*}$ & $-12.07904^{*}$ \\
\cline { 2 - 5 } & 2 & -12.02675 & -9.582631 & -11.18304 \\
\hline
\end{tabular}

\footnotetext{
* indicates lag order selected by the criterion calculated using EViews-7
} 


\section{JOHANSEN COINTEGRATION TEST}

To notice long run relationship among variables considered in the study, Trace Statistics and Maximum Eigen value statistics are applied and their results are given in tables 4 and 5 . Statistics provided in tables demonstrate that there are two co-integrated vectors present in specified models leading the analysis towards long run coefficient values of the variables.

Table 4: Trace Statistics

\begin{tabular}{clcccc}
\hline Models & $\begin{array}{l}\text { Hypothesized } \\
\text { No. of CE(s) }\end{array}$ & $\begin{array}{c}\text { Eigen } \\
\text { Value }\end{array}$ & $\begin{array}{c}\text { Trace } \\
\text { Statistics }\end{array}$ & $\begin{array}{c}\text { 0.05 Critical } \\
\text { Value }\end{array}$ & Probability \\
\hline \multirow{5}{*}{ I } & None $*$ & 0.655379 & 99.62748 & 76.97277 & 0.0004 \\
\cline { 2 - 6 } & At most 1 $*$ & 0.604178 & 62.34160 & 54.07904 & 0.0077 \\
\cline { 2 - 6 } & At most 2 & 0.352924 & 29.90389 & 35.19275 & 0.1663 \\
\cline { 2 - 6 } & At most 3 & 0.228773 & 14.66868 & 20.26184 & 0.2460 \\
\cline { 2 - 6 } & At most 4 & 0.147288 & 5.576651 & 9.164546 & 0.2261 \\
\hline \multirow{3}{*}{ II } & None $*$ & 0.587129 & 85.63223 & 76.97277 & 0.0094 \\
\cline { 2 - 6 } & At most 1 & 0.452046 & 54.67057 & 54.07904 & 0.0442 \\
\cline { 2 - 6 } & At most 2 & 0.388652 & 33.61580 & 35.19275 & 0.0733 \\
\cline { 2 - 6 } & At most 3 & 0.250821 & 16.39270 & 20.26184 & 0.1568 \\
\cline { 2 - 6 } & At most 4 & 0.164383 & 6.285484 & 9.164546 & 0.1698 \\
\hline
\end{tabular}

Table 5: Eigenvalue Statistics

\begin{tabular}{clcccc}
\hline Models & $\begin{array}{l}\text { Hypothesized } \\
\text { No. of CE(s) }\end{array}$ & $\begin{array}{c}\text { Eigen } \\
\text { Value }\end{array}$ & $\begin{array}{c}\text { Max-Eigen } \\
\text { Statistic }\end{array}$ & $\begin{array}{c}\mathbf{0 . 0 5} \text { Critical } \\
\text { Value }\end{array}$ & Probability \\
\hline \multirow{5}{*}{ I } & None ${ }^{*}$ & 0.655379 & 37.28588 & 34.80587 & 0.0248 \\
\cline { 2 - 6 } & At most 1 $*$ & 0.604178 & 32.43771 & 28.58808 & 0.0153 \\
\cline { 2 - 6 } & At most 2 & 0.352924 & 15.23521 & 22.29962 & 0.3560 \\
\cline { 2 - 6 } & At most 3 & 0.228773 & 9.092031 & 15.89210 & 0.4240 \\
\cline { 2 - 6 } & At most 4 & 0.147288 & 5.576651 & 9.164546 & 0.2261 \\
\hline \multirow{3}{*}{ II } & None & 0.587129 & 30.96166 & 34.80587 & 0.1341 \\
\cline { 2 - 6 } & At most 1 & 0.452046 & 21.05476 & 28.58808 & 0.3357 \\
\cline { 2 - 6 } & At most 2 & 0.388652 & 17.22310 & 22.29962 & 0.2200 \\
\cline { 2 - 6 } & At most 3 & 0.250821 & 10.10722 & 15.89210 & 0.3247 \\
\cline { 2 - 6 } & At most 4 & 0.164383 & 6.285484 & 9.164546 & 0.1698 \\
\hline
\end{tabular}

\section{LONG RUN RESULTS}

Long run results of the econometric models are presented in table 6 which include government expenditure in model 1 and government revenue in model 2. There are five columns shown in the table, first column is about variables, second column is related to long run coefficient values, third column shows standard errors, $\mathrm{t}$ - statistics are provided in $4^{\text {th }}$ column and fifth column contains conclusion about significance of variables. 
Labor force is thought to be imperative factor for real output of economy. It may be significant cause of higher economic growth in the long run. Unfortunately, in this study, it is exhibited to be insignificant but with negative coefficient value in the long run.

The study finds positive relationship between Real GDP and Investment in Pakistan. The sign of coefficient is statistically significant at 1 percent level of significance justifying 1.28 and 1.52 percent rise in real GDP due to one percent rise in investment. Higher investment will increase industries in the economy which will increase production capacities of the industries causing higher real GDP in the longrun. Investment elasticities of real GDP are 1.28 and 1.52 .

In the study, Government expenditure is revealed to be positive with real GDP in the long run with statistically significant coefficient value. Higher government expenditure will start new projects and lead to higher real GDP. It proposes that 1.28 percent enhancement in real GDP will appear due to one percent higher Government expenditure in Pakistan in the long run. Elasticity of real GDP with respect to government expenditure is 1.28.

Table 6: Johansen Results

\begin{tabular}{lcccc}
\hline Variables & Coefficient & $\begin{array}{c}\text { Standard } \\
\text { Error } \\
\text { Model }-\mathbf{I}\end{array}$ & t - value & Conclusion \\
\hline ELF & -0.5643 & 0.7320 & -0.7709 & Insignificant \\
\hline INV & 1.2869 & 0.2950 & 4.3625 & Significant \\
\hline GEXP & 1.2817 & 0.2571 & 4.9850 & Significant \\
\hline GDPDEF & -0.5320 & 0.2426 & -2.2028 & Significant \\
\hline Intercept & 1.1009 & 1.3179 & 0.8354 & Insignificant \\
\hline ELF & -0.1684 & Model - II & & \\
\hline INV & 1.5252 & 0.6111 & -0.2756 & Insignificant \\
\hline GREV & -1.5248 & 0.3184 & 4.7897 & Significant \\
\hline GDPDEF & -0.2559 & 0.1312 & -5.1956 & Significant \\
\hline Intercept & 0.3522 & 1.1888 & -1.9231 & Significant \\
\hline
\end{tabular}

Government revenue is appeared to be negative with real GDP of Pakistan in the long run. The coefficient value is -1.52 with statistically significant probability value. Generally, it is seen that government impose taxes for deficit financing of its budget that adversely affect purchasing power of the economy. It would lower aggregate demand of the economy and hence real GDP as well in the long run. On the average, real GDP of 
Pakistan will lower by 1.52 percent due to one percent higher government revenue in the long run. Elasticity of real GDP with respect to government revenue is -1.52 .

GDP deflator is tended to decrease real GDP of Pakistan as shown in current analysis with significant coefficient value. Because when GDP deflator increases, it will increase the prices of the commodities thereby decreasing the purchasing power of people. The decreased aggregate demand will discourage the producers to produce so in this way total production will fall causing a decrease in real GDP. One percent higher price level will become cause of declining real GDP by 0.53 and 0.25 percent on the average in the longrun. Elasticities of real GDP with respect to GDP Deflator (Price Level) are -0.53 and -0.25 .

\section{E. SHORT RUN RESULTS}

Vector error correction model (VECM), the short run results are described in table 7. In the short run, speed of adjustment term is the most important thing and it shows that how much time would be taken by the economy to reach at long run equilibrium from the short run equilibrium. The economy will converge towards long run equilibrium when there is negative sign attached with error correction term.

Table 7: Short run Dynamics

\begin{tabular}{|c|c|c|c|c|}
\hline \multirow{2}{*}{ Variables } & \multicolumn{2}{|c|}{ Model - I: D(LRGDP) } & \multicolumn{2}{|c|}{ Model - II: D(LRGDP) } \\
\hline & Coefficient & T - statistics & Coefficient & T - statistics \\
\hline Speed of Adjustment Term & -0.067095 & -0.42697 & -0.014921 & -1.50752 \\
\hline D(LRGDP(-1)) & -0.076885 & -0.25915 & -0.026563 & -0.09121 \\
\hline D(LRGDP(-2)) & -0.124011 & -0.37854 & -0.064628 & -0.21220 \\
\hline D(LELF(-1)) & -0.161864 & -0.05049 & 0.703149 & 0.20148 \\
\hline D(LELF(-2)) & 1.763538 & 0.49515 & -0.100325 & -0.02884 \\
\hline D(LINV(-1)) & 0.393431 & 0.26597 & 1.068361 & 0.60216 \\
\hline D(LINV(-2)) & -0.129886 & -0.08550 & 1.024489 & 0.62921 \\
\hline D(LGOVTEXP(-1)) & -2.284153 & -1.51530 & --- & \\
\hline D(LGOVTEXP (-2)) & 1.421572 & 1.05921 & --- & \\
\hline D(LGDPDEF(-1)) & 1.659110 & 0.69239 & -0.893162 & -0.37453 \\
\hline D(LGDPDEF(-2)) & -1.553321 & -0.65122 & -2.907070 & -1.24025 \\
\hline D(LTGOVR(-1)) & --- & & 0.951497 & 0.58298 \\
\hline D(LTGOVR(-2)) & --- & & 0.133065 & 0.07929 \\
\hline Constant & 0.210144 & 0.46043 & 0.004761 & 0.00887 \\
\hline
\end{tabular}

\section{CONCLUDING REMARKS}

Fiscal policy does have considerable influence on real gross domestic product on Pakistan's economy by accelerating aggregate demand, employment and investment. Its 
importance motivates young researchers to carry on the objective of analyzing effectiveness of fiscal policy on real GDP of Pakistan in the long run. For fulfillment of this aim, the study uses times series data ranging from 1976 to 2012. For elasticities, Log-Log form of the models is utilized. Stationary is checked through Augmented Dickey Fuller - unit root test. Akaike Information Criterion, Schwarz information Criterion, Hannan - Quinn Information Criterions are used to select an appropriate lag length. Long run results are estimated using Johansson cointegration test and for short run, vector error correction model is employed.

Unit root test confirm the use of Johansen Cointegration test due to having stationary of variables examined at 1 st difference. Following an appropriate lag length, the results of long run reveal that investment and government expenditure have positive association with real GDP while government revenue and GDP Deflator are negatively related with real GDP in the long run. According to the short run results, economy converges towards the long run equilibrium due to the negative sign with error correction term.

To attain higher growth rates, the government of Pakistan should provide training and skill development programs for labor force to become more efficient and effective at their workplace. Government expenditure should be enhanced to attain macroeconomic objectives like employment generation, stable prices, higher growth rates, exchange rate stability etc. Government revenue would be favorable if there is no any change in taxation policy that may be harmful for the society.

\section{REFERENCES}

Aghion, P. and P. Howitt (1992) A Model of Growth through Creative Destruction. Econometrica, 60, 323-351.

Akaike, H. (1987), Factor analysis and AIC. Psychometrika, 52(3), 317 - 332.

Al Bataineh, I. M. (2012). The Impact of Government Expenditures on Economic Growth in Jordan. Interdisciplinary Journal of Contemporary Research in Business, 4(6), $1320-1338$.

Aladejare,S. (2013). Government spending and economic Growth: Evidence from Nigeria. MPRA Paper No. 43916, 1- 22. 
Alexiou, C. (2009). Government Spending and Economic Growth: Econometric Evidence from the South Eastern Europe (SEE). Journal of Economic and Social Research, 11(1), $1-6$.

Asghar, N., Azim, P. and Rehman, H. (2011). Impact of Government Spending in Social Sectors on Economic Growth: A Case Study of Pakistan. Journal of Business \& Economics, 3 (2), 214 - 234.

Asteriou, D. (2005). Applied Econometrics: A modern approach using EViews and Microfit, Palgrave Macmillan.

Atif, M., Shahab, S. and Mahmood, M. T. (2012). The Nexus between Economic Growth, Investment and Taxes: Empirical Evidence from Pakistan. Academic Research International, 3(2), 530 - 537.

Dickey, D. A. and Fuller, W. A. (1979). Distribution of the estimators for autoregressive time series with a unit root. Journal of the American Statistical Association, 74, 427 431.

Doessel, D. and Valadkhani, A. (2003). The effect of government on economic growth in Fiji. Singapore Economic Review, 48(1), 27 - 38.

Ferede, E. and Dahlby, B. (2012). The Impact of Tax Cuts on Economic Growth: Evidence from the Canadian Provinces. National Tax Journal, 65 (3), 563 - 594.

Ghali, K. (1997). Government Spending and Economic Growth in Saudi Arabia. Journal of Economic Development, 22(2),165-172.

Ghali, K. (2003). Government Spending, Budget Financing, and Economic Growth: The Tunisian Experience. The Journal of Developing Areas, 36(2), 19 - 37.

Gomme, P. (1993) Money and Growth Revisited: Measuring the Costs of Inflation in an Endogenous Growth Model. Journal of Monetary Economics, 32, 51-77.

Govt. of Pakistan (2000). 50 years of Pakistan in Statistics, Federal Bureau of Statistics, Statistical Division.

Govt. of Pakistan (2011). Handbook of Statistics on Pakistan Economy 2010, State Bank of Pakistan.

Govt. of Pakistan (2012-13). Economic Survey of Pakistan, Federal Bureau of Statistics, Statistical Division.

Gujarati, D. N. and Porter, D. C. (2009). Basic Econometrics, $5^{\text {th }}$ Edition.

Johansen, S (1988). Statistical Analysis of Cointegrating Vectors. Journal of Economic Dynamics and Control, 12, 231-54.

Johansen, S. and Juselius, K. (1990). Maximum Likelihood Estimation and Inferences on Cointegration - with applications to the demand for money. Oxford Bulletin of Economics and Statistics, 52, $169-210$.

Jones, C. I. (1995). Time Series Tests of Endogenous Growth Models. The Quarterly Journal of Economics, 110(2), 495-525.

Kim, S. J. (1992) Taxes, Growth and Welfare in an Endogenous Growth Model. PhD. dissertation. 
Loizides, J. and Vamvoukas, G. (2005). Government expenditure and economic growth. Journal of Applied Economics, 8(1), 125 - 152.

Lucas (1988) On the Mechanisms of Economic Development. Journal of Monetary Economics. 22, 3-42.

Nurudeen, A. and Usman. A. (2010). Government Expenditure and Economic Growth in Nigeria, 1970-2008: A Disaggregated Analysis. Business and Economics Journal, $4,1-11$.

Nworji, I. D., Okwu, A. T., Obiwuru, T. C. and Nworji, L. O. (2012). Effects of Public Expenditure on Economic Growth in Nigeria: A Disaggregated Time Series Analysis. International Journal of Management Sciences and Business Research, 1(7), 1 - 15.

Padda, I. H. and Akram, N. (2009). The Impact of Tax Policies on Economic Growth: Evidence from Asian Economies. The Pakistan Development Review, 48(4), 961 971.

Rebelo, S. (1991) Long-run Policy Analysis and Long-run Growth. The Journal of Political Economy, 99(3), 500-521.

Romer, P. M. (1986) Increasing Returns and Long-Run Growth. The Journal of Political Economy, 94(5), 1002-1037.

Romer, P. M. (1990) Endogenous Technological Change. The Journal of Political Economy, 98(5), S71-S102.

World Bank, (2013). World Development Indicators. World Bank, Washington, DC. 